\title{
Analisis Kecepatan Data Seismik 2D Menggunakan Metode Semblance pada Lapangan $X$ Lepas Pantai Papua Nugini
}

\author{
Tri Ananda Komala*, Elistia Liza Namigo \\ Jurusan Fisika Universitas Andalas \\ Kampus Limau Manis, Pauh Padang 25163 \\ *triianandakomala@gmail.com
}

\begin{abstract}
ABSTRAK
Telah dilakukan analisis kecepatan dengan menggunakan metode semblance pada data seismik 2D Lapangan X Papua Nugini. Software yang digunakan adalah software Geomage. Analisis kecepatan dilakukan pada tiga CDP (Common Depth Point) yaitu CDP 480, CDP 826 dan CDP 1740 yang dianggap memiliki pola semblance yang baik. Pola semblance yang baik didefinisikan sebagai pola semblance yang menunjukkan keteraturan nilai koherensi maksimum sehingga memudahkan proses pemilihan nilai kecepatan. Proses pemilihan nilai kecepatan dilakukan secara interaktif sampai lengkungan hiperbola sinyal refleksi berubah menjadi datar. Rentang nilai kecepatannya yang didapat pada CDP 1740 yaitu $1870,25-2230,40 \mathrm{~m} / \mathrm{s}$, CDP 480 yaitu 1650,32 - 2510,81 m/s, dan CDP 826 yaitu 1561,15 - 2617,53 $\mathrm{m} / \mathrm{s}$. Nilai kecepatan yang didapat akan digunakan untuk proses stacking dan migrasi. Hasil stacking dan migrasi menunjukkan respon yang baik dimana reflektor di kedalaman terlihat semakin jelas dan kebanyakan noise inkoherennya pun hilang.

Kata kunci: analisis kecepatan, Lapangan X Lepas Pantai Papua Nugini, metode semblance,
\end{abstract}

\section{ABSTRACT}

Velocity analysis was conducted by using semblance method on 2D seismic data in Papua New Guinea Field X area. Using Geomage software. Velocity analysis was carried out on three CDPs (Common Depth Point), CDP 480, CDP 826 and CDP 1740 to investigate good semblance pattern. Good semblance pattern is defined as a pattern which indicates regularity semblance of coherence maximum value, so it will be easy to pick the velocity values. The process of selecting was performed interactively until the arch of hyperbolic reflection signal turns flat. The range values of velocity analysis obtained at the CDP 1740 is 1870.25 - 2230.40 m/s, CDP 480 is $1650.32-2510.81 \mathrm{~m} / \mathrm{s}$, and CDP 826 is 1561.15 $2617.53 \mathrm{~m} / \mathrm{s}$. The velocity values will be used for stacking and migration process. Stacking and migration show good response where the reflectors in depth are more apparent and most incoherent noises are gone.

Keywords: velocity analysis, Papua New Guinea Field X area, semblance method, Papua New Guinea Field $X$ area

\section{PENDAHULUAN}

Pengolahan data seismik bertujuan untuk menghasilkan penampang seismik dengan $\mathrm{S} / \mathrm{N}$ (signal to ratio noise) yang baik tanpa mengubah bentuk kenampakan-kenampakan refleksi, sehingga dapat dilakukan interpretasi pada struktur dari perlapisan di bawah permukaan bumi (Monalia, 2011). Salah satu hal terpenting dari pengolahan data seismik adalah analisis kecepatan. Analisis kecepatan diperlukan untuk menghitung kedalaman reflektor bawah permukaan berdasarkan data seismik yang direkam dalam domain waktu (Priyono, 2011). Analisis kecepatan dilakukan dengan memperkirakan nilai kecepatan pada suatu titik pada data seismik. Tahap analisis kecepatan harus dilakukan setepat dan semaksimal mungkin karena informasi kecepatan tersebut digunakan untuk proses stacking dan migrasi (Riyadi, 2011). Metode analisis kecepatan yang digunakan pada penelitian ini adalah metode semblance. Metode semblance merupakan atribut turunan waktu yang dimanfaatkan untuk mengukur similaritas antar trace seismik. Metode semblance dimanfaatkan untuk menonjolkan perubahan lateral seismik akibat adanya perbedaan kondisi geologi (Sadzali, 2011).

Metode semblance memiliki beberapa keunggulan. Pertama, menghasilkan kecepatan dan waktu yang akurat untuk proses stacking. Sehingga lengkungan hiperbola sinyal telah dirubah menjadi datar menggunakan hasil analisis kecepatan. Kedua, metode ini juga tidak perlu menentukan semblance mana yang cocok untuk sinyal-sinyal refleksi tertentu, karena pemilihan semblance dilakukan dengan cara memilih koherensi yang mempunyai kecepatan maksimum. Ketiga, metode semblance memberikan gambaran geologi yang cukup akurat 
tanpa harus melakukan stacking terlebih dahulu dan model penampang yang terbentuk bisa dilakukan estimasi nilai kecepatan RMS (root mean square) serta interval pada masing-masing lapisan (Pratama, 2008).

Penelitian ini dilakukan pada data seismik 2D Lapangan X lepas pantai Papua Nugini yang merupakan salah satu perairan laut yang memiliki kedalaman bervariasi serta struktur geologi yang kompleks sehingga perlu dilakukan analisis kecepatan.

\section{METODE}

Sebagaimana disebutkan dalam pendahuluan, penelitian ini dilakukan pada data seismik data seismik 2D Lapangan X lepas pantai Papua Nugini, dengan parameter seismik panjang streamer $1,2 \mathrm{~km}$, jumlah channels 48 channels, jumlah CDP 1858, jumlah tembakan 906, interval channels $25 \mathrm{~m}$, interval tembakan $25 \mathrm{~m}$, laju penyampelan $2 \mathrm{~ms}$ dan total dari trace 43488. Adapun tahap-tahap pengolahan data seismik yang akan dilakukan adalah automatic gain control, filtering, analisis kecepatan, stacking dan migrasi.

\subsection{Automatic Gain Control (AGC)}

Automatic gain control dilakukan untuk memunculkan amplitudo-amplitudo gelombang seismik yang lemah. Automatic gain control digunakan untuk menghilangkan efek spherical divergent yang menyebabkan tidak meratanya distribusi energi dan amplitudo pada trace-trace seismik. Selain menguatkan sinyal automatic gain control juga menguatkan noise maka dilakukan proses filtering.

\subsection{Filtering}

Data seismik yang setelah dilakukan automatic gain control selanjutnya akan dilakukan proses filtering. Proses filtering dilakukan untuk memisahkan frekuensi yang diinginkan dan tidak diinginkan karena saat akuisisi berjalan receiver akan menangkap semua gelombang yang mengenainya, termasuk noise dengan frekuensi rendah (seperti ground roll) dan frekuensi tinggi (ambient noise). Apabila noise dengan frekuensi tinggi dan rendah tersebut tidak dihilangkan, maka akan menurunkan kualitas data seismik. Filtering biasanya menggunakan band pass fitering karena membuang frekuensi di bawah $10 \mathrm{~Hz}$ dan di atas $70 \mathrm{~Hz}$.

\subsection{Analisis kecepatan}

Analisis kecepatan dilakukan untuk mendapatkan penampang kecepatan bawah permukaan. Kecepatan ini akan digunakan pada tahap stacking dan migrasi. Pemilihan kecepatan dilakukan dengan metode picking yang tepat pada nilai semblance yang tinggi yang biasanya ditunjukkan warna merah atau coklat. Proses ini dilakukan sampai didapat fungsi kecepatan yang benar-benar tepat dan akurat yang ditandai dengan datarnya lengkungan hiperbola dari reflektor pada CDP gather sampai reflektor menjadi datar .

\subsection{Stacking}

Stacking dilakukan untuk menjumlahkan trace-trace dalam satu gather data yang bertujuan untuk mempertinggi sinyal to noise ratio (S/N) karena sinyal yang koheren akan saling memperkuat dan noise yang bersifat tidak koheren saling menghilangkan. Selain itu, stacking akan mengurangi noise bersifat koheren

\subsection{Migrasi}

Migrasi dilakukan untuk memindahkan reflektor miring ke posisi yang sebenarnya pada penampang seismik. Migrasi juga mampu menghilangkan efek difraksi serta efek bowtie sehingga dapat memperjelas gambaran struktur detil bawah permukaan. Selain itu, migrasi dapat dipandang sebagai suatu proses yang dapat meningkatkan resolusi spasial penampang seismik. Melalui migrasi didapatkan sejumlah parameter yang berbeda sebagai koreksi yaitu migrasi memperbesarkan sudut kemiringan dan memperbaiki resolusi lateral.

\section{HASIL DAN DISKUSI}

\subsection{Penampang Data Seismik Sebelum Analisis Kecepatan}

Gambar 1(a) dan Gambar 1(b) merupakan penampang seismik dari data mentah. Dari penampang tersebut terlihat bahwa data seismik mengandung banyak noise seperti multiple, 
pola-pola difraksi, gelombang langsung, efek bowtie dan noise kolom air. Di samping itu terlihat bahwa kenampakan reflektor terutama di kedalaman kurang jelas sehingga obyek geologi kemenerusan reflektor sulit diidentifikasi.

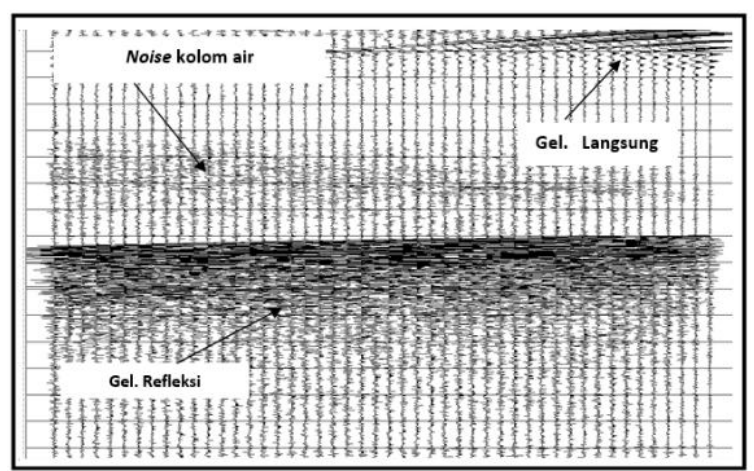

(a)

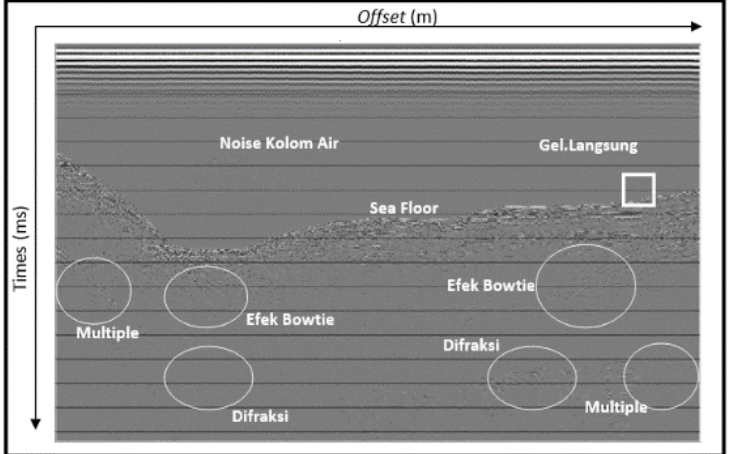

(b)

Gambar 1 (a) Identifikasi noise pada penampang seismik (b) Identifikasi noise pada penampang seismik (bagian kotak putih pada Gambar 1(a) diperbesar)

Sebelum dilakukan analisis kecepatan, data seismik harus dikondisikan terlebih dahulu. Pengkondisian bertujuan untuk meningkatkan kualitas data seismik dengan meminimalisir noise-noise dan meningkatkan $\mathrm{S} / \mathrm{N}$ ratio. Proses pengkondisian data seismik ini dilakukan melalui dua tahap yaitu tahap automatic gain control dan filtering.

\subsection{Hasil Proses Automatic Gain Control}

Proses Automatic Gain Control (AGC) diterapkan pada penampang seismik Gambar 2. Setelah diterapkan AGC dihasilkan tampilan reflektor yang lebih jelas dan tegas (Gambar 2) jika dibandingkan dengan tampilan sebelum (Gambar 1(a)). Pada proses ini terlihat amplitudo noise yang ada juga dikuatkan sebagai contoh noise kolom air yang terlihat sangat jelas pada penampang seismik (Gambar 2). Noise-noise ini harus dihilangkan sebelum dilakukan analisis kecepatan dengan cara filtering.

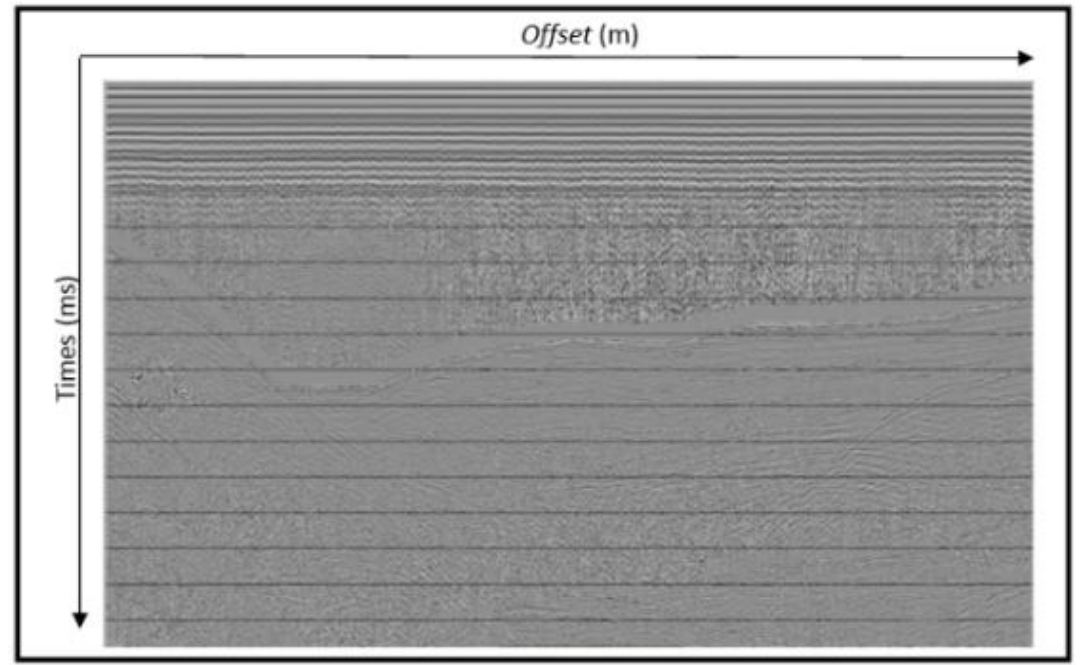

Gambar 2 Penampang seismik setelah dilakukan proses AGC

\subsection{Hasil Proses Filtering}

Gambar 3 menunjukkan tampilan data seismik sebelum dan sesudah proses filtering. Sebelum dilakukan filtering, terlihat trace seismik yang mengandung noise koheren dan noise inkoheren (kotak merah), setelah filtering noise koheren diminimalisir karena proses filtering membuang frekuensi yang bersifat noise. Selanjutnya akan dilakukan proses analisis kecepatan pada penampang seismik yang sudah berkurang noise-nya untuk mendapatkan nilai kecepatan 
yang akan digunakan pada proses stacking dan migrasi sehingga didapatkan data seismik dengan resolusi yang lebih baik.

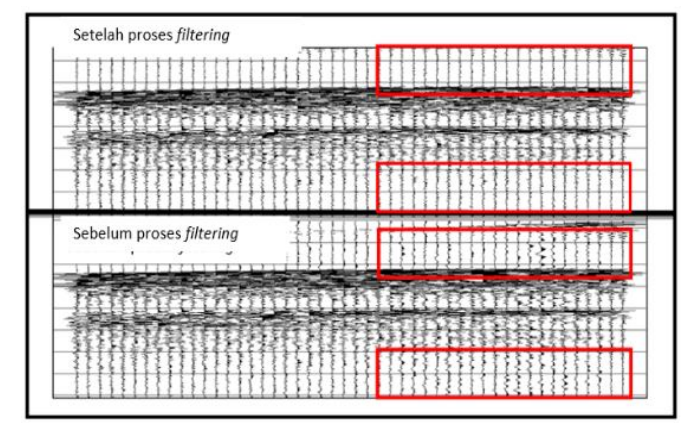

Gambar 3 Sebelum dan setelah proses filtering

\subsection{Hasil Proses Analisis Kecepatan}

Analisis kecepatan dilakukan dengan mem-plot data seismik terhadap waktu dan kecepatan. Setelah itu dilakukan Picking nilai kecepatan pada spectrum yang memiliki nilai semblance yang tinggi yang ditunjukkan pada semblance warna merah. Dari data total yang ada 1858 CDP yang ada pada data seismik, terdapat banyak CDP yang tidak memiliki pola semblance yang baik. CDP yang tidak memiliki pola semblance baik menyulitkan untuk melakukan pemilihan kecepatan pada semblance tersebut. Selain ketidakteraturan, display semblance pada CDP tidak menunjukkan nilai kontur kecepatan maksimum yang tepat. Hal ini dapat menyebabkan ketidakmunculan reflektor pada saat stacking nanti. Ketidakteraturan pada pola semblance disebabkan oleh karena pada CDP gather di nomor CDP tersebut tidak menunjukkan kemenerusan refleksi yang baik dari sinyal-sinyal seismik yang ada, sehingga kontur kecepatan maksimum yang diharapkan pada semblance tidak muncul. Analisis kecepatan dilakukan hanya beberapa CDP yang memiliki pola semblance yang baik yaitu CDP 480, CDP 826 dan CDP 1740 (Gambar 4).

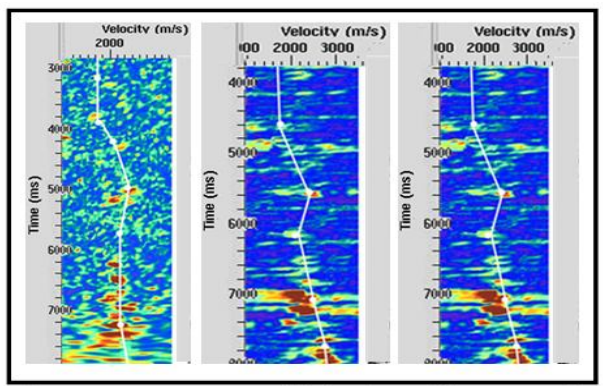

Gambar 4 CDP yang memiliki pola semblance yang kurang baik

\subsubsection{Hasil Analisis kecepatan pada CDP 1740}

Analisis kecepatan pertama dilakukan pada CDP 1740, Gambar 5 menunjukkan pemilihan nilai kecepatan yang dilakukan berulang kali sampai lengkungan hiperbola menjadi datar agar didapatkan nilai kecepatan yang tepat. Kontur kecepatan tepat ditunjukkan pada waktu $3170,23 \mathrm{~ms}, 3850,15 \mathrm{~ms}, 4135,72 \mathrm{~ms}, 4862,36 \mathrm{~ms}, 5765,05 \mathrm{~ms}$ dan $7252,16 \mathrm{~ms}$.

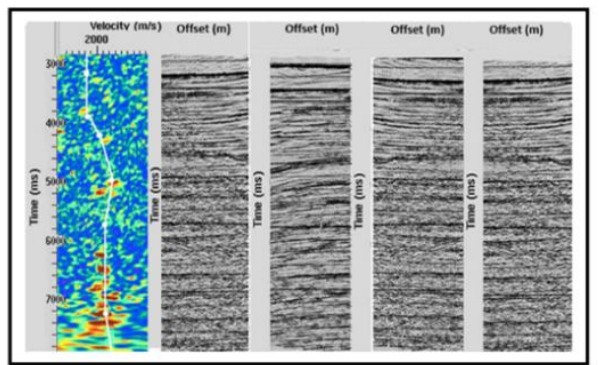

Gambar 5 Picking kecepatan pada CDP 1740 
Pada CDP 1740 sedikit sulit menentukan kontur warna yang memiliki kecepatan yang tinggi. Hal ini dikarenakan kecepatan tidak muncul direntang waktu awal yang menyebabkan nilai kecepatan yang tidak konstan seperti terlihat pada Tabel 1. Pada waktu 4862,36 ms yang naik menjadi $2208,33 \mathrm{~m} / \mathrm{s}$, sedangkan pada waktu selanjutnya memiliki nilai kecepatan yang relatif sama. Adapun rentang nilai waktunya 3170,23 - 7252,16 ms dan nilai kecepatan 1810,25 $2230,40 \mathrm{~m} / \mathrm{s}$

Tabel 1 Nilai kecepatan pada CDP 1740

\begin{tabular}{cc}
\hline $\mathbf{T}(\mathbf{m s})$ & $\mathbf{V}(\mathbf{m} / \mathbf{s})$ \\
\hline 3170,23 & 1810,25 \\
3850,15 & 1830,12 \\
4135,72 & 2070,56 \\
4862,36 & 2208,33 \\
5765,05 & 2117,09 \\
7252,16 & 2230,40 \\
\hline
\end{tabular}

\subsubsection{Hasil Proses Analisis kecepatan pada CDP 480}

Analisis kecepatan dilakukan pada CDP 480, pemilihan kecepatan dilakukan terhadap semblance berwarna merah yang memiliki kecepatan maksimum berkali-kali sampai reflektor berubah jadi datar. Gambar 6 menunjukkan bahwa kontur kecepatan yang tepat disekitar waktu $4620,03 \mathrm{~ms}, 5660,13 \mathrm{~ms}, 6201,23 \mathrm{~ms}, 7110,52 \mathrm{~ms}, 7762,71 \mathrm{~ms}$. Nilai rentang nilai waktu 4620,03 - 7762,71 ms dan rentang nilai kecepatan 1750,32 - 2510,81 m/s.

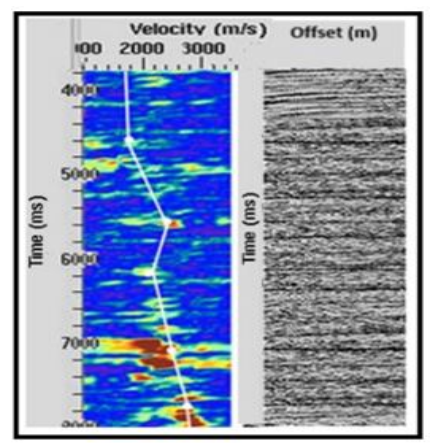

Gambar 6 Picking kecepatan pada CDP 480

Pada Tabel 2 dapat dilihat nilai kecepatan untuk CDP 480 yang mewakili setiap reflektor.Pada waktu 5660,13 ms terjadi kenaikan nilai kecepatan, sedangkan pada waktu 6701,23 ms terjadi penurunan nilai kecepatan.

Tabel 2 Nilai kecepatan pada CDP 480

\begin{tabular}{ll}
\hline $\mathbf{T}(\mathbf{m s})$ & $\mathbf{V}(\mathbf{m} / \mathbf{s})$ \\
\hline 4620,03 & 1760,32 \\
5660,13 & 2566,53 \\
6210,23 & 1916,32 \\
7110,52 & 2210,37 \\
7762,71 & 2510,81 \\
\hline
\end{tabular}

\subsubsection{Hasil Proses Analisis kecepatan pada CDP 826}

Analisis kecepatan berikutnya dilakukan pada CDP 826, pemilihan kecepatan dilakukan dengan memilih semblance yang warna merah. Gambar 7 menunjukkan bahwa kontur kecepatan yang tepat ditujukkan pada waktu 3513,07 ms, 4652,21 ms, 5190,62 ms, 6030,17 ms, dan 6932,16 ms. Dalam melakukan pemilihan kecepatan harus diperhatikan setiap kontur kecepatan karena dalam setiap rentang waktu yang berdekatan akan ada lebih dari satu kontur kecepatan yang menunjukkan nilai kecepatan yang maksimum. Hal ini dapat terlihat pada 
waktu sekitar rentang 6000 - 7000 ms, maka dipilih yang nilai kecepatannya lebih besar dan konstan dibandingkan kecepatan sebelumnya sehingga sinyal-sinyal refleksi menjadi datar.

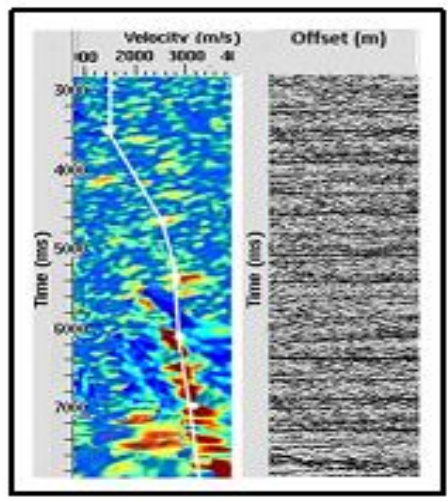

Gambar 7 Picking kecepatan pada CDP 826

Pada Tabel 3 dapat dilihat nilai kecepatan cenderung bertambah terhadap waktu, hal ini sesuai dengan prinsip kecepatan yang bertambah seiiring bertambahnya waktu. Adapun rentang nilai waktunya $3513,07-6932,16 \mathrm{~ms}$ dan kecepatannya $1561,15-3177,53 \mathrm{~m} / \mathrm{s}$.

Tabel 3 Nilai kecepatan pada CDP 826

\begin{tabular}{cc}
\hline $\mathbf{T}(\mathbf{m s})$ & $\mathbf{V ( m / s )}$ \\
\hline 3513,07 & 1561,15 \\
4652,21 & 2236,07 \\
5190,62 & 2836,38 \\
6030,17 & 2781,15 \\
6932,16 & 3117,53 \\
\hline
\end{tabular}

Setelah dilakukan analisis kecepatan, didapatkan nilai kecepatan untuk setiap CDP. Nilai kecepatan ini sudah bisa mewakili setiap reflektor yang mungkin ada nantinya dari hasil proses stacking.

\subsection{Hasil Proses Stacking}

Gambar 8 merupakan hasil stacking, terlihat pada lingkaran putih reflektor yang dihasilkan cukup tegas dan terlihat jelas pola reflektornya. Hal ini dikarenakan proses stacking dilakukan berdasarkan CDP dimana trace-trace yang tergabung pada satu CDP dan telah dilakukan analisis kecepatan untuk mendapatkan trace yang lebih tajam dan bebas dari noise yang tidak koheren. Stacking tidak efektif dalam menghilangkan atau menekan multiple dan difraksi serta efek bowtie sehingga masih memperlihatkan gambaran lapisan yang kasar. Selain itu reflektor-reflektor masih belum berada pada posisi sebenarnya, untuk itu perlu dilakukan tahap migrasi.

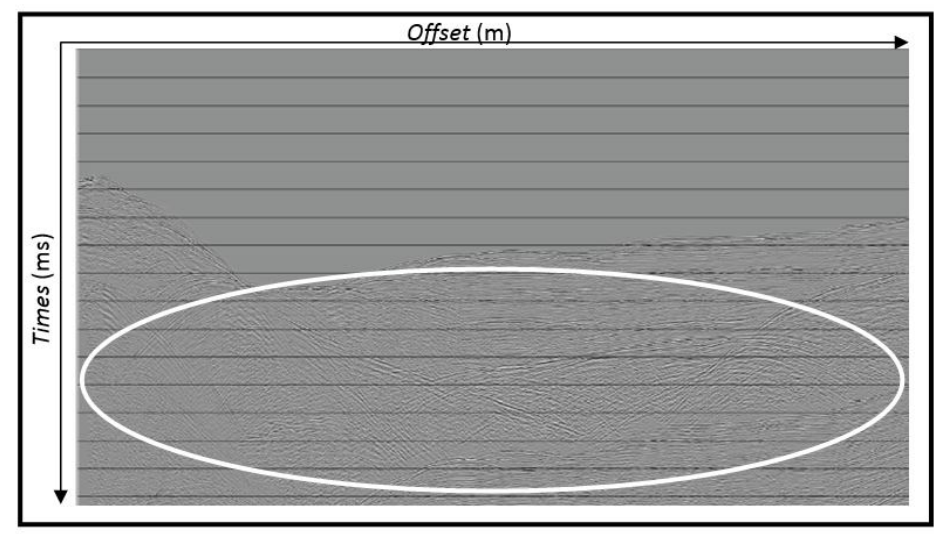

Gambar 8 Penampang seismik setelah dilakukan proses stacking 


\subsection{Hasil Proses Migrasi}

Pada Gambar 9 terlihat bahwa reflektor-reflektornya terutama di posisi yang dalam terlihat lebih jelas dan efek difraksinya serta efek bowtie secara umum hilang jika dibandingkan sebelum dilakukan proses migrasi. Hal ini karena proses migrasi berefek untuk memperbesarkan sudut kemirigan, memperpendek reflektor, memindahkan reflektor kearah up dip serta memperbaiki resolusi lateral. Tetapi muncul noise yang berbentuk lengkunganlengkungan hiperbola yang berada dikolom. Hal ini disebabkan karena belum optimalnya tahap processing dalam rangka mengeliminasi noise sebelum dilakukan picking kecepatan sangat sensitif terhadap noise.

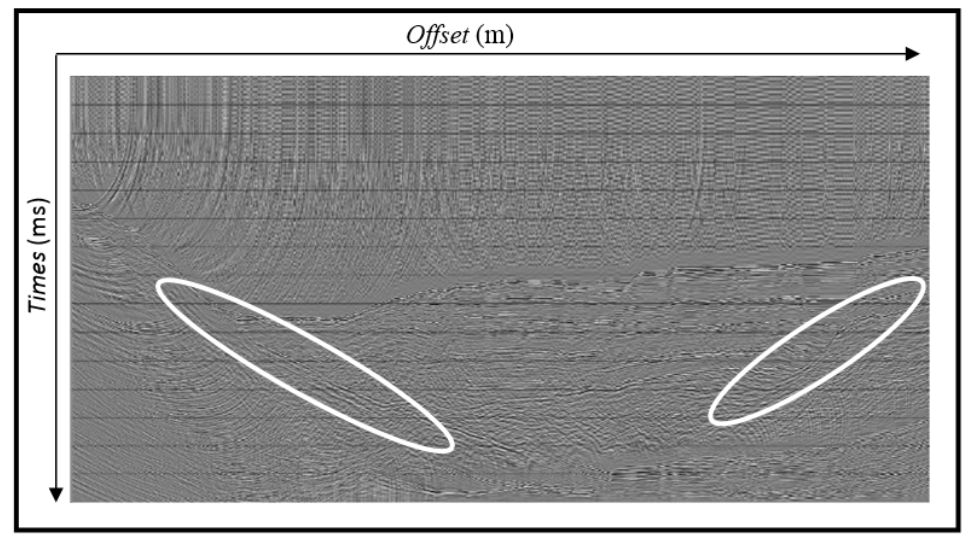

Gambar 9 Penampang seismik setelah dilakukan proses migrasi

\section{KESIMPULAN}

Analisis kecepatan dilakukan hanya pada beberapa CDP yang mempunyai pola semblance yang baik yaitu, CDP 480, CDP 826 dan CDP 1740. Nilai rentang kecepatannya pada CDP 1740 yaitu 1810,25 - 2230,40 m/s, CDP 480 yaitu $1760,32-2510,81 \mathrm{~m} / \mathrm{s}$, dan CDP 826 yaitu 1561,15 - 3117,53 m/s. Kondisi geologi bawah permukaan Lapangan X lepas pantai Papua Nugini terdapat patahan graben dan jika dilihat dari rentang kecepatanya diperkirakan bawah terdapat batuan pasir dan tanah liat. Pada proses akhir yaitu migrasi didapatkan penampang penampang seismik dengan resolusi tinggi. Hal ini terbukti dari reflektornya terlihat tegas dan jelas, selain itu minimnya noise pada data seismik.

\section{DAFTAR PUSTAKA}

Monalia, 2011, Analisis Model Kecepatan Berdasarkan Tomografi Refleksi Waktu Tempuh, Tesis, PPS UI, Depok.

Pratama, S.Y., 2008, Estimasi Kecepatan Interval Melalui Pemilihan Semblace Berdasarkan NMO Secara Otomatis, Skripsi, Departemen Fisika UI, Depok.

Priyono, 2011, Seismik Eksplorasi, Jurusan Geofisika dan Meteorologi, ITB, Bandung.

Riyadi, P., 2011, Analisis Kecepatan data Seismik Refleksi 2D Zona Darat Menggunakan Metode Semblance, Skripsi, UIN, Jakarta.

Sadzali, 2011, Komparasi Kohersi Model Data Seismik 3D Menggunakan Metode Semblance dan Struktur Eigen Untuk Mendekteksi Sesar, Skripsi, UI, Depok, 